\title{
Editorial Special issue to commemorate Dr David T Thompson, FRSC
}

This issue is a Special Issue to commemorate Dr David T Thompson, who sadly died in June after a sudden and short illness, just short of his 75th birthday. David played an active role at Gold Bulletin, initially as Technical Editor (1996 - 2003) and as an active member of the Editorial team since. He will be known to many contributors to the journal over the last 12 years. His substantial contribution has played no small part in the success of Gold Bulletin, particularly in restoring the quality of the journal to its original high levels.

This Special Issue commemorates David's contribution, not only to Gold Bulletin, but also to the world of science and its application, particularly in the field of gold catalysis. It is a tribute to his standing that our Editorial Board wished to contribute to this issue. We also include a paper co-authored by David with Geoff Bond, prepared shortly before his death. We would like to thank all those who have contributed or refereed papers for this Special Issue at such short notice and helped to achieve publication on time. We trust this is a fitting tribute to an outstanding man and scientist.

The editorial team:

Richard Holliday, Editor

Tricia Harris, Technical Editor

Chris Corti

\section{An appreciation: Dr David T Thompson, 1934 - 2009}

David Thompson is widely known in the chemistry community as an eminent and respected expert in the relatively new field of gold catalysis. He also made a major contribution to Gold Bulletin journal and its growing success as the scientific journal focussed on gold. Sadly, he died after a sudden and serious illness on the 18th June 2009 just before his 75th birthday.

\section{Contribution to the world of gold}

I have had the pleasure of knowing David as a colleague and good friend for over 30 years, initially as fellow research managers at the Johnson Matthey Technology Centre, but more recently in his role as consultant to World Gold Council. In 1996, I took over responsibility as Editor for Gold Bulletin journal at World Gold Council and quickly realised I needed some support if we were to bring this well established scientific journal back to the high standards it had enjoyed under its original editor, Leslie Hunt (also of Johnson Matthey). I turned to David who came on board in a consultancy role as Technical Editor. It was a major effort to get contributions of papers for the first issue in a very short timescale and the journal published on time. We succeeded and built from that point. David knew little of the state of gold chemistry at that time and offered to look into it. He quickly reported back that gold chemistry was relatively underdeveloped compared to the other precious metals and that there were some exciting developments in gold catalysis appearing in the literature.

The rest is history, as they say. David built upon his contacts in academia and industry and developed a strong interest in gold catalysis, both its science and its commercial application. This was an area we quickly identified as having strong potential for new industrial applications for gold (a major plank in our strategy at World Gold Council). He became a strong 
advocate and presented papers on the exciting potential of gold catalysts for industrial applications at many major international conferences on behalf of World Gold Council and later also for Project AUTEK in South Africa. He is particularly known for his joint paper with Geoff Bond on the mechanism of gold catalysis in the oxidation of $\mathrm{CO}$, published in Gold Bulletin in 2000, and for the first book on gold catalysis, Catalysis by Gold, published in 2006 and jointly authored with Geoff Bond and Catherine Louis. He was very proud of this achievement and especially when it was translated into Chinese.

Following the successful gold conference in Hanau, Germany in 1996, he became a strong supporter of the need for regular gold conferences and this led to World Gold Council taking on this responsibility. The next one was held in 2001 - the 'Catalytic Gold' conference - in Cape Town, and David contributed actively to its organisation. This has since been followed by Gold 2003 in Vancouver, in which David acted as technical co-ordinator, Gold 2006 in Limerick and Gold 2009 in Heidelberg. In all these, David played an active role both on the Organising committees and on the Catalyst technical committees. Their undoubted success owes a lot to David's leadership and interest.

The Cape Town conference led to two developments in which David played a leading role. Firstly, the production of 4 gold reference catalysts for World Gold Council in Japan and Italy, which have proved immensely successful, and secondly, the production of the quarterly CatGold News, a newsletter linking the gold catalysis community and its activities. He also became involved with the EU-funded project in gold catalysis, Auricat, a programme involving several European universities and companies.

More recently, David became a consultant in gold catalysis for Project AUTEK at Mintek in South Africa, where he made a major contribution to their work. His colleagues at Mintek have offered the following words:

"David was a consultant to Project AuTEK, an industrial gold R\&D project based at Mintek in South Africa, for the past four and a half years. Although he was appointed as consultant, he very quickly became part of the AuTEK team and had interactions with many of the AuTEK researchers over the years. David's visits to South Africa gave AuTEK team members the opportunity to interact with a very knowledgeable person in the field of gold catalysis.
He played an important role in the AuTEK gold catalysis programme by sharing the latest literature, marketing of AuTEK's AUROlite ${ }^{\mathrm{TM}}$ range of catalysts, facilitating collaborations, joint publications, and contributions at international conferences. Through these efforts and his other publications, in particular his work on the book "Catalysis by Gold", David championed the use of gold catalysts in emission control and petrochemical/fine chemical applications. David's enthusiasm for gold catalysis will be dearly missed by the AuTEK team."

\section{His early career}

David trained as an organic chemist at Imperial College, London, obtaining his PhD under Prof. Lloyd Jackman in 1958. He then did post-doctoral studies at the University of California with Prof. Saul Winstein before returning to the $\mathrm{UK}$ where he joined $\mathrm{ICl}$ at their Akers Research Laboratory, working with Prof Joseph Chatt on the chemistry of the platinum group metals. Here he applied his NMR spectroscopy expertise in organic chemistry to inorganic chemistry. After 1 year, he moved on to ICl's corporate research laboratories at Runcorn working on homogeneous and polymerisation catalysis.

In 1975, David became research manager of the catalyst department at the Johnson Matthey Research Laboratory at Wembley (in West London), which later transferred to Sonning Common in Oxfordshire, working on homogeneous rhodiumbased catalysis and autocatalysts, both now commercially successful technologies. He moved on to manage a new interdisciplinary research department at the Johnson Matthey Technology Centre (as it had now become) involving materials science and pharmaceutical research and interaction with academia on collaborative research projects. This was also a success. However, on his return from a trip to the USA in 1991, David was informed that his research department was to be closed and that he would be retired early. This was a blow but a leisurely retirement was not for David. He undertook consultancy for a number of European and Japanese companies before joining World Gold Council as a consultant in 1996, as detailed above, and making his reputation in gold catalysis.

\section{The man}

David has had a long career in applied research, some 50 years after gaining his PhD. He appears to many people as a quiet, unassuming person, but this neglects his underlying passion and quiet dogged determination to succeed at what he wants 
to achieve. He also had a knack of getting the best out of his researchers who worked for him. Innovative scientists are not always the easiest to manage!

There is no doubt that his later career in gold research is where he has made his greatest contribution and it has also brought him considerable respect in the scientific community. I believe this was the part of his career he most enjoyed too. On learning of his death, many of his colleagues and friends have described him as a Gentleman. Of that, there is no doubt! He was a lovely person and a great friend. His contribution to World Gold Council's work to promote new industrial applications and to Gold Bulletin was substantial and much appreciated. He will be sorely missed.

\section{Christopher Corti}

Editor, Gold Bulletin, 1996 - 2009

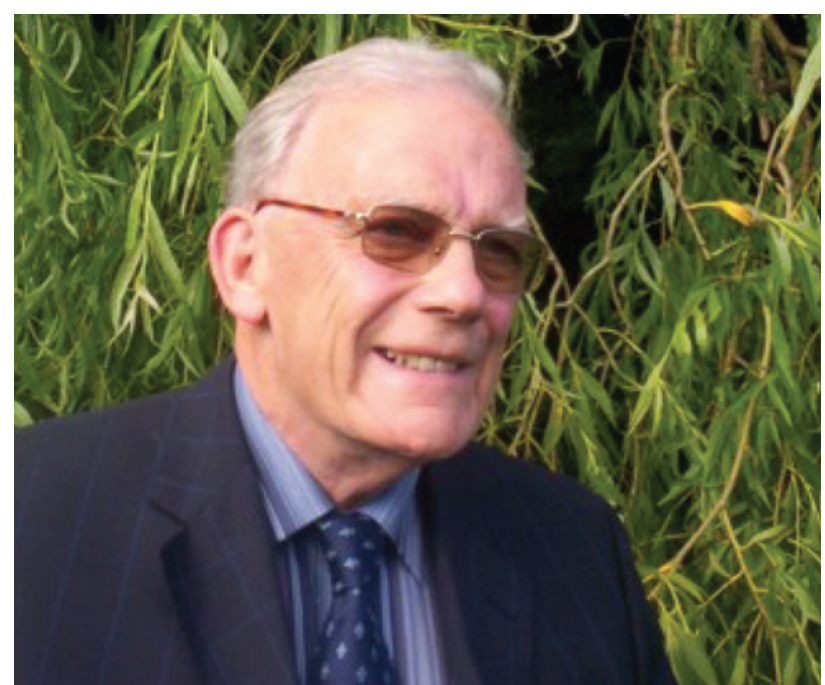

\section{Dr David T Thompson}

1934 - 2009 